\title{
Subject float, low subject trapping, and case in Icelandic
}

\author{
Halldór Ármann Sigurðsson \\ Lund University
}

\begin{abstract}
This article describes and discusses two peculiar sets of (in)definiteness facts applying to subjects in Icelandic, here referred to as Subject Float and Low Subject Trapping. Indefinite subjects (commonly quantified) in presentational sentences and related clause types may either occupy the complement position within the predicate phrase or "float" into various positions in the middle field. This is Subject Float, yielding variation such as "There would (many farmers) then (many farmers) probably (many farmers) be (?*many farmers) elected (many farmers)". Conversely, and unexpectedly, definite NP subjects of some adjectival and verbal predicates must stay in the complement position. This is Low Subject Trapping, yielding orders such as "there is cold radiator-the" and "there cooled radiator-the". It is shown that the licensing of subject NPs in the various positions in Subject Float and in the complement position in Low Subject Trapping is unrelated to specific grammatical cases, thus refuting the widely adopted case approach to NP licensing. Although Icelandic case marking has been widely discussed, Subject Float and Low Subject Trapping have not previously received a detailed scrutiny; these phenomena provide additional and partly new knockout arguments against the case approach to NP licensing and NP movement. While high NP raising to subject (Spec,IP) is unaffected by case, it seems to involve both Person and Topic matching.
\end{abstract}

\section{Introduction ${ }^{1}$}

The Definiteness Effect or the Indefiniteness Requirement (Thráinsson 2007: 319 ff.) refers to the fact that "late subjects" or expletive associates must be indefinite in examples such as (1) and (2).

1 The research for this article was partly funded by a grant from Riksbankens Jubileumsfond, P15:-0389:1. I am grateful to an anonymous reviewer, and also to Anders Holmberg, Einar Freyr Sigurðsson, Elisabet Engdahl, and Gunilla Lindholm, for helpful discussions and remarks.

Ken Ramshøj Christensen, Henrik Jørgensen \& Johanna L. Wood (eds.). 2019.

The Sign of the V-Papers in Honour of Sten Vikner.

Dept. of English, School of Communication \& Culture, Aarhus University, pp. 591-618, doi:10.7146/aul.348.116. (C) The author(s). 
(1) a. There is a man in the garden.

b. * There is the man in the garden.

(2) a. There has probably been a farmer elected to the board.

b. * There has probably been the farmer elected to the board.

See Milsark (1977), Safir (1985), Belletti (1988), Lasnik (1992), among many. Sten Vikner discussed facts of this sort across Germanic and Romance at length in his Oxford volume on verb movement and expletive subjects (1995).

A peculiar fact is that English requires raising of the associate into the vicinity (or the "complement position") of be, as illustrated in (3).

(3) a. There have been three books iritten $_{-}$about this.

b. * There have been written three books about this.

(Holmberg 2002: 86)

As discussed by Vikner in his 1995 volume, and also by Holmberg (2002), the Scandinavian languages behave differently. For one thing, they allow the associate to stay in the object position, as illustrated for Swedish in (4a) and for Icelandic in $(4 b){ }^{2}$

(4) a. Swedish (Holmberg 2002: 86)

Det har blivit skrivet tre böcker om detta. there has been written three books about this

'There have been three books written about this.'

b. Icelandic (Holmberg 2002: 86)

раð hafa verið skrifaðar prjár bækur um petta.

there has been written three books about this

'There have been three books written about this.'

All the Scandinavian languages observe (a version of) the Indefiniteness Requirement, though. See (5a) for Swedish and (5b) for Icelandic.

2 Swedish has two types of passives, a periphrastic one (e.g., bli skrivet 'be written') and a morphological s-passive (e.g., skrivas ‘be written'). As discussed by Engdahl (2017), the order V-NP, with the associate in the object position, is much rarer and more marked in periphrastic passives than in s-passives; it usually requires rather special contexts. The relevant point is that Scandinavian languages allow indefinite associates to stay in the object position in passives, albeit under somewhat varying conditions. 
(5) a. Swedish

* Det har blivit skrivet böckerna/de.

there have been written books-the/they

\section{b. Icelandic}

* Рað hafar verið skrifaðar bækurnar/pær.
there have been written books-the/they

The canonical declarative subject positions in Icelandic, as in other Scandinavian languages, are the preverbal position in direct word order ("John arrived yesterday", "John had arrived yesterday") or the position immediately following the finite verb in inverted orders ("Yesterday arrived John", "Yesterday had John arrived"). However, Icelandic displays two sets of peculiar and poorly understood (in)definiteness facts applying to subjects. First, quantified indefinite subjects can "float" and show up in various positions in the middle field above (to the left of) the $\mathrm{vP}$ or the predicate phrase. ${ }^{3}$ Second, certain definite NP subjects must stay within the predicate phrase, a sort of an anti-definiteness effect. I refer to these phenomena as Subject Float and Low Subject Trapping. I will describe these phenomena here. Even though they have to some extent been discussed in the extensive literature on Icelandic syntax, a more detailed and precise description is called for. I aim to provide such a description here.

As we will see, the described facts speak very clearly against the widely adopted assumption that specific cases (abstract or not) account for the positional licensing of NPs; in particular, it has been assumed that subjects move to the canonical subject position (Spec,IP) "in order" to get nominative case, overt or abstract. This assumption, Vergnaud's conjecture, goes back to Jean-Roger Vergnaud's famous 1977 letter to Chomsky and Lasnik and was developed in Chomsky's Lectures on government and binding (1981). Possibly, though, NPs are partly licensed by having some case, regardless of which. However, that is a very general and vague idea, hard or impossible to test. Vergnaud's conjecture, on the other hand, was a scientific hypothesis in the sense that it is possible to test. When put to

3 The predicate phrase contains the main verb and its complements, plus non-finite auxiliaries, to the exclusion of sentence adverbials in the middle field. The boundary between the predicate phrase and the middle field is blurred by finite verb raising when the finite verb is the main verb. If we assume that auxiliaries are adjoined to vP, the predicate phrase is larger than vP, but if they are stacked little vs the resulting extended vP is equivalent with the predicate phrase (to the exclusion of the raised finite verb). 
a test, however, it fails. This has been argued previously by many, on the basis of Icelandic facts (see H. Sigurðsson 2012 and the references there). This article adds further evidence that Vergnaud's conjecture was on the wrong track and must be rejected; an alternative account of NP licensing must be sought for. ${ }^{4}$

\section{Subject Float}

A well-known fact is that quantifiers can float, showing up in various positions in the clause (Sportiche 1988; Bošković 2004). This applies to clauses with all major types of verbs in Icelandic, including transitive, unergative, unaccusative/ergative, and passive verbs. I illustrate this for a passive predicate in (6) and (7).

\section{(6) Icelandic}

a. Allar stelpurnar mundu pá sennilega hafa verið kosnar. all girls-the would then probably have been elected 'All the girls would then probably have been elected.'

b. Stelpurnar mundu allar bá sennilega hafa verið kosnar.

c. Stelpurnar mundu pá allar sennilega hafa verið kosnar.

d. Stelpurnar mundu pá sennilega allar hafa verið kosnar.

e. ?* Stelpurnar mundu pá sennilega hafa allar verið kosnar.

f. ?* Stelpurnar mundu pá sennilega hafa verið allar kosnar.

g. ?* Stelpurnar mundu pá sennilega hafa verið kosnar allar. ${ }^{5}$

(7) ... would $1_{\overline{\mathrm{ok}}}$ then $2_{\mathrm{ok}}$ probably $3{ }_{\mathrm{ok}}$ have $4_{?^{*}}$ been $5_{?^{*}}$ elected ${ }_{?^{*}}$

The potential positions between non-finite verbs do not easily tolerate lexical material (with the partial exception of negative polarity items, see (14)), so I will largely disregard these in the following. As for the sentence adverbials, one might want to assume that they come from another dimension than arguments and verbs, in a multi-dimensional approach to

4 It is not a coincidence that case has played such a central role in generative syntax. Case does not pose immediately obvious or acute problems for the credo that syntax is context free, while other major grammatical categories do, including Person, Tense, Mood, and Gender.

5 The heavier quantifier allar með tölu, lit. "all in number", meaning roughly 'each and every(one)', can be right adjoined to the $\mathrm{vP}$ or the clause (yielding the same surface order as $(6 \mathrm{~g}))$. I set this aside. 
phrase structure (see the discussion in Bobaljik 1999, and the references there). I do not take a stand on this issue here. The only thing regarding sentence adverbials that matters for my purposes is that their order is strict, and that quantifiers and quantified subjects can be interspersed between them.

Indefinite subjects that contain a quantifier or consist of a bare quantifier show similar distributional properties as does the quantifier in (6). This is illustrated in (8) and (9).

(8) a. аð mundu margir bændur pá sennilega verða kosnir there would many farmers then probably be(come) elected 1 stjórnina.

in board-the

'There would then probably be many farmers elected to the board.' 'Many farmers would then probably be elected to the board.'

b. að mundu pá margir bændur sennilega verða kosnir í stjórnina.

c. Баð mundu pá sennilega margir bændur verða kosnir í stjórnina.

d. ?*ॅað mundu pá sennilega verða margir bændur kosnir í stjórnina.

e. Pað mundu pá sennilega verða kosnir margir bændur í stjórnina. ${ }^{6}$

(9) a. аð mundu margir pá sennilega verða kosnir í stjórnina.

'There would then probably be many elected to the board.'

'Many would then probably be elected to the board.'

b. að mundu pá margir sennilega verða kosnir í stjórnina.

c. Dað mundu pá sennilega margir verða kosnir í stjórnina.

d. ?*'aðð mundu pá sennilega verða margir kosnir í stjórnina.

e. að mundu pá sennilega verða kosnir margir í stjórnina.

Expletive the C-domain (see Thráinsson 1979; Platzack 1983, and many others since, including Engdahl et al. 2018). According to the analysis in H. Sigurðsson (2010), the expletive is in the low C-domain in both main and subordinate

\footnotetext{
6 Margir bcendur can also be heavy NP-shifted to the right of the vP (or the clause), yielding the order "there would then probably be elected to board-the many farmers". I set this aside. I am not concerned with transitive expletive constructions here (see, e.g., Thráinsson 2007), but they show largely similar patterns: "There would (many farmers) then (many farmers) probably (many farmers) have (*many farmers) read (*many farmers) book-the (?many farmers)".
} 
clauses. $^{7}$ As we will see, Subject Float is independent of the presence of the expletive. The floating NP in Subject Float constructions is the subject. ${ }^{8}$

Margir in (9) and margir beendur in (8) may either have a specific or a non-specific reading. It is difficult to distinguish between these readings, but my intuition is that only the non-specific reading is available in (8e) and (9e), where the subject is in the object position. When the subject is in the highest position, as in (8a) and (9a), I only get the specific reading, while I get both readings for the middle field positions in the b- and c-examples.

Similar facts apply to some other quantifiers, including, nokkrir 'a few (people)', einhverjir 'some (people)' and numerals like fjórir 'four', while other quantifiers, including sumir 'some (people)' and allir 'everybody, all (people)' behave slightly differently (bare sumir and allir are for example awkward in the object position). ${ }^{9}$ I will not try to sort this out here; it would take us too far. ${ }^{10}$

Bare indefinites behave differently from quantifier subjects; they are usually only "happy" in the object position, as illustrated in (10).

\section{a. ??ధаð mundu bændur pá sennilega verða kosnir í there would farmers then probably be(come) elected in stjórnina. board-the} Intended: 'Some (non-specific) farmers would then be elected to the board.'

b. ?* Рað mundu pá bændur sennilega verða kosnir í stjórnina.

c. ?* Рað mundu pá sennilega bændur verða kosnir í stjórnina.

d. ?* Рað mundu pá sennilega verða bændur kosnir í stjórnina.

e. аð mundu pá sennilega verða kosnir bændur í stjórnina.

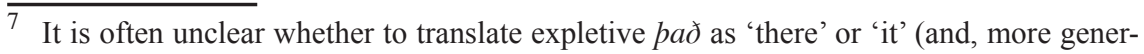
ally, how to translate Icelandic impersonal constructions). For simplicity, I consistently use 'there' in the glosses.

8 Alternatively, one might want to assume that impersonal and presentational constructions have an expletive null-subject in Spec,vP that forms a chain with the overt subject NP (and presumably also with the expletive, when it is present, in the spirit of Safir 1985). I do not take a stand on this issue here but see Sigurðardóttir \& Eythórsson (2017) and Wood (2017) for discussions of related ideas. Bare margir in (9e) is also a bit marked (while, e.g., mjög margir 'very many' feels entirely natural in the object position).

${ }^{10}$ Another complicating factor that I will not discuss here either is that the judgments change if one adds more sentence adverbials in the middle field, for example the hearsay evidentiality marker víst 'they say, allegedly' (yielding pá _ víst__ sennilega _) and the negation ekki (yielding pá ( víst) sennilega $e k k i$ ). 
Much the same applies to indefinite subjects that are modified by an adjective, such as duglegir boendur 'efficient farmers', gamlir boendur 'old farmers'. ${ }^{11}$

The basic structure of vPs in languages like English and the other Germanic VO languages is commonly assumed to be as sketched in (11).

$$
\left[{ }_{\mathrm{vP}} \operatorname{Spec}(\text { ifier }) \mathrm{v}\left[{ }_{\mathrm{VP}} \mathrm{V} \operatorname{Compl}(\text { ement })\right]\right]
$$

Subjects of unaccusatives and passives are taken to be generated in the complement position, to the right of the main verb. Transitive subjects, in turn, are assumed to be generated in the specifier position, Spec, vP, that is, the position to the immediate left of the main verb. However, as in many other languages (see Alexiadou \& Anagnostopoulou 2001), transitive subjects are not usually allowed to surface in Spec,vP in Icelandic. This is illustrated in (12).

(12) a. Баð mundu margir (bændur) hafa keypt bókina. therewould many (farmers) have bought book-the 'Many (farmers) would have bought the book.' 'There are many (farmers) who have bought the book.'

b. * Раð mundu hafa margir (bændur) keypt bókina. there would have many (farmers) bought book-the

Quantifiers and quantified subjects are usually not "happy" in Spec,vP in passives and unaccusatives either. We see this in the passives in (8d), (9d), and (10d) above, and we see the same for the unaccusative hverfa 'disappear' in (13d).

(13) a. Рað mundu margir bílar pá sennilega hafa horfið. there would many cars then probably have disappeared 'Probably, many cars would then have disappeared.'

\footnotetext{
${ }^{11}$ However, in clauses with vera 'be' as the main verb, adjectival modification has grammaticality effects. See the discussion in Thráinsson (2007: 318-322) of the different behavior of köttur 'a cat' vs. svartur köttur 'a black cat'.
} 
b. аð mundu pá margir bílar sennilega hafa horfið.

c. Баð mundu pá sennilega margir bílar hafa horfið.

d. ?*'раð mundu pá sennilega hafa margir bílar horfið.

e. аð mundu bá sennilega hafa horfið margir bílar.

However, the negative polarity item nein- 'any' behaves differently. When it modifies an NP the two are relatively "comfortable" in Spec,vP, in particular if nein- is focalized. ${ }^{12}$ See (14). ${ }^{13}$

(14) a. ? Рað mundu pá sennilega ekki hafa NEINIR bændur there would then probably not have any farmers

keypt bókina.

bought book-the

'Probably, no farmers would then have bought the book.'

'Probably, the book would then not have been bought by any farmers.'

b. Рað mundu pá sennilega ekki hafa verið NEINIR there would then probably not have been any

bændur kosnir.

farmers elected

'Probably, there would then not have been any farmers elected.'

c. Рað mundu pá sennilega ekki hafa NEINIR bílar there would then probably not have any cars horfið.

disappeared

'Probably, no cars would then have disappeared.'

12 This is marked, though. In all three examples in (14) the order "there would then probably not any farmers/cars have ...", with "any farmers/cars" in the middle field, is more natural (and does not require strong focus). Also, nein- alone is ungrammatical in Spec,vP ("*there would then probably not have any bought book-the", etc.), and so is eng(i)- (enginn, etc.) "one-no" = "no one', which incorporates the negation (as in "*there would then probably have one-no bought book-the"). These facts might relate to the fact that negative objects are commonly raised in the Scandinavian languages (see Thráinsson 2007: 82 ff. and the references there), yielding orders like "I have one-no book bought".

13 More generally, the negation affects judgments of Subject Float clauses (see H. Sigurðsson 2000: 83), but, as this is presumably due to independent scope effects (rather than the float itself), I set it aside. 
Spec, $\mathrm{vP}$ is commonly accessible for indefinite subjects in passives in for example English and Swedish (usually under a participle number agreement condition in the latter, see Holmberg 2002). The limited access of floating quantifiers and indefinite subjects to $\mathrm{Spec}, \mathrm{vP}$ in Icelandic is curious. ${ }^{14}$ In contrast, in English and Swedish, indefinite subjects cannot usually raise into the middle field, that is, the postverbal I-domain, as opposed to Icelandic (see, e.g., Engdahl et al. 2018). ${ }^{15}$ I set these differences aside here.

The Subject Float examples we have looked at so far have the expletive pað in initial position. However, Icelandic Subject Float is largely independent of the expletive, and, more generally, of the initial position. I illustrate this for only the lowest I-domain position in (15); the sentence in (15c) is a narrative style verb-initial declarative (see H. Sigurðsson 1990, 2018).

(15) a. Pví mundu pá kannski margir bændur verða kosnir í thus would then perhaps many farmers be elected in stjórnina.

board-the

'Thus, there would perhaps be many farmers elected to the board.'

b. Mundu pá kannski margir bændur verða kosnir í stjórnina? 'Would there then perhaps be many farmers elected to the board?'

c. Mundu pví kannski margir bændur verða kosnir í stjórnina. 'Thus, there would perhaps be many farmers elected to the board.'

d. ... að pá mundu kannski margir bændur verða kosnir í ... that then would perhaps many farmers be elected in stjórnina. board-the '... that there would then perhaps be many farmers elected to the board.'

14 One could say that the participle has an EPP [Extended Projection Principle] feature in English and Swedish, attracting the subject into Spec,vP, while Icelandic lacks such a feature (see Holmberg 2002). However, unless one has a general theory of EPP, that is just a restatement of the facts.

15 "I" in "I-domain" refers to Infl, the position of the finite verb (when it does not raise to $\mathrm{C}$ ). The postverbal I-domain is the space between the finite verb and the highest or the first non-finite verb. In "there would then probably not many farmers be elected to board-the", "then", "probably", "not", and "many farmers" are all in the postverbal Idomain, while "be", "elected", and "to board-the" are within the predicate phrase. 
Now, reconsider (8), repeated here as (16).

(16) a. аð mundu margir bændur pá sennilega verða kosnir there would many farmers then probably be(come) elected í stjórnina. in board-the

'There would then probably be many farmers elected to the board.' 'Many farmers would then probably be elected to the board.'

b. Pað mundu pá margir bændur sennilega verða kosnir í stjórnina.

c. Pað mundu pá sennilega margir bændur verða kosnir í stjórnina.

d. ?*Баð mundu pá sennilega verða margir bændur kosnir í stjórnina.

e. Pað mundu pá sennilega verða kosnir margir bændur í stjórnina.

$$
\begin{aligned}
& \text {... would }{ }_{\overline{\mathrm{ok}}} \text { then } 2 \frac{\mathrm{ok}}{\text { probably }} 3_{\overline{\mathrm{ok}}} \text { be(come) }{ }_{\frac{?^{*}}{}}^{\text {elected }} \\
& 5_{\overline{\mathrm{ok}}} \text { to board-the }
\end{aligned}
$$

It is unclear, to say the least, what licenses all these potential indefinite quantified subject positions (or quantifier subject positions, cf. (9)). Subject Float is at least partly semantically and syntactically regulated, relating to specificity, but the effects are vague and unclear. Partly, the variation seems to be due to mere "PF sloppiness". ${ }^{16}$ In particular, there are no clear reading differences between the low I-domain positions. ${ }^{17}$ There is a slight preference for a specific reading in (16b), "there would then many farmers probably", and a slight preference for a non-specific reading in (16c), "there would then probably many farmers", but, as far as I can judge, both readings are possible in both positions.

The Subject Float facts are unrelated to specific cases. The floating subject is nominative in all the examples we have looked at so far, but ${ }^{16}$ Quite possibly, though, there are some intonation correlates. It would be interesting to test this.

17 The high I-domain position is the position immediately following the finite verb in main clauses, occupied by definite subjects in inverted orders, as in "Then would farmers-the probably have been elected", and by indefinite subjects in orders like "There would many farmers then probably have been elected". The other positions in the I-domain are low(er) I-domain positions. These are entirely descriptive terms; the high I-domain positions in inverted orders and in presentational sentences are probably distinct (this has been debated, but I set it aside here). 
quirky (non-nominative) subjects behave the same. ${ }^{18}$ This is illustrated for the dative subject mörgum boendum in (18). ${ }^{19}$

(18) a. раð mundi mörgum bændum pá sennilega verða there would many farmers.DAT then probably be(come) bjargað.

rescued

'There would then probably be many farmers rescued.'

'Many farmers would then probably be rescued.'

b. аð mundi pá mörgum bændum sennilega verða bjargað.

c. аð mundi pá sennilega mörgum bændum verða bjargað.

d. ?* Рað mundi pá sennilega verða mörgum bændum bjargað.

e. аð mundi pá sennilega verða bjargað mörgum bændum.

Since Chomsky (1981), it has been widely assumed that subject movement to Spec,IP, as in The farmers would then probably be rescued, is triggered by abstract nominative case ("Case"). Full NPs in English have no morphologically visible case, but they might well have abstract case; abstract case in the sense "covert but active case" is arguably a fact (see, e.g., Sigurðsson 2008; Wood 2017). However, definite subjects move to Spec,IP in Icelandic, much as in English, but this applies to quirky subjects as well as nominative ones: Baendunum. DAT mundi pá sennilega verða bjargad 'The farmers would then probably be rescued' vs. *Dá mundi sennilega verða bjargað baendunum. DAT (see Andrews 1976; Thráinsson 1979; and many others since). On the face of it, this would seem to disprove that subject movement to Spec,IP is triggered by abstract nominative case. One might think that it is possible to get around this problem, though, and thereby save the abstract nominative case trigger hypothesis, by assuming that quirky subjects in Spec,IP are assigned invisible abstract nominative case, on top of the quirky case (see Jónsson 1996, and also the critical discussion in Thráinsson 2007: 192 ff.). However, this has no bearing on

18 This has been repeatedly pointed out in previous work (H. Sigurðsson 1989, 2000, etc.). Icelandic quirky subjects have been widely discussed. See for example Thráinsson (2007), H. Sigurðsson (2012), and the references cited in these works.

19 Parallel facts are found for (much rarer) genitive subjects: "There would (many farmers. GEN) then (many farmers.GEN) probably (many farmers.GEN) be (?*many farmers.GEN) missed (many farmers.GEN)" (miss = sakna). 
the Subject Float facts. ${ }^{20}$ Floating subjects can show up in a number of positions in the middle field, below Spec,IP, and also in the complement position, regardless of case. If abstract nominative case were the factor that licenses subjects in all these positions, then such case would either have multiple sources within the clause or be able to percolate rather freely down the whole clausal structure, which in turn would mean that abstract nominative case has zero explanatory value with regard to NP licensing. It would be available in multiple positions, hence unavailable as an explanation or an account of where subjects can be spelled out.

In this section, we have seen that that there is extensive Subject Float in Icelandic. It has an intriguing relationship to definiteness (and sometimes focus), but it has nothing to do with case, which is not surprising since argument licensing in Icelandic is in general not affected by case (see $\mathrm{H}$. Sigurðsson 1989, 2008, 2012, and the references there).$^{21}$ In the next section, we will encounter another intriguing argument-licensing phenomenon that is also unrelated to case.

\section{Low Subject Trapping}

Definite subjects are excluded in Subject Float constructions. See (19).
a. * Раð mundu bændurnir pá sennilega verða kosnir í there would farmers-the then probably be(come) elected in stjórnina.
board-the
'The farmers would then probably be elected to the board.'

\footnotetext{
${ }^{20}$ Nominative objects and agreement with such objects, as in "Me.DAT would.3PL like these horses.NOM", 'I would like these horses', also pose a problem for the abstract nominative case approach (H. Sigurðsson 1996 and much subsequent work; see also Thráinsson 2007: $232 \mathrm{ff}$. and the references there)

21 The high subject position and the object position are also available for indefinite subjects in both regular ECM and experiencer ECM in Icelandic. Regular ECM: "I believed many farmers.ACC have been elected", and "I believed have been elected many farmers. ACC". Experiencer ECM: "Me.DAT seemed many farmers.NOM have been elected", and "Me.DAT seemed have been elected many farmers.NOM". In contrast, definite subjects are licit in only the high subject position of both types of ECM infinitives (the Definiteness Effect). These facts speak strongly against a case-related approach to argument licensing. I must set this aside here, though, but see H. Sigurðsson (2012).
} 
b. * Рað mundu pá bændurnir sennilega verða kosnir í stjórnina.

c. * Рað mundu pá sennilega bændurnir verða kosnir í stjórnina.

d. * Pað mundu pá sennilega verða bændurnir kosnir í stjórnina.

e. * Рað mundu pá sennilega verða kosnir bændurnir í stjórnina.

However, Icelandic displays a number of exceptions from the Indefiniteness Requirement, discussed by Thráinsson (2007: 317 ff.; see also Rögnvaldsson 1982 [1990], 1984; H. Sigurðsson 1989; Jónsson 2000, 2005; Vagnsnes 2002; Indriðadóttir 2014; Engdahl et al. 2018). One is that definite subjects quantified by all- 'all, every' are well-formed in the high and low I-domain (Vangsnes 2002; Thráinsson 2007: 317 ff.), but ungrammatical within the predicate phrase, as illustrated in $(20){ }^{22}$

(20) a. аð mundu allir bændurnir pá sennilega hafa verið kosnir. there would all farmers-the then probably have been elected 'All the farmers would then probably have been elected.'

b. ? Баð mundu pá allir bændurnir sennilega hafa verið kosnir.

c. аð mundu pá sennilega allir bændurnir hafa verið kosnir.

d. * Рað mundu pá sennilega hafa allir bændurnir verið kosnir.

e. ?? Баð mundu pá sennilega hafa verið kosnir allir bændurnir.

The expletive does not seem to be responsible for these patterns. See (21) and the narrative style V1 declaratives in (22).

(21) a. Pá mundu sennilega allir bændurnir hafa verið kosnir.

'Then all the famers would probably have been elected.'

b. * Pá mundu sennilega hafa verið kosnir allir bændurnir.

(22) a. Mundu pví sennilega allir bændurnir hafa verið kosnir. 'Thus, all the farmers would probably have been elected.'

b. * Mundu pví sennilega hafa verið kosnir allir bændurnir.

$\overline{22}$ Flestir 'most' and definite partitives, such as tveir af bcendunum.DAT, tveir bondanna. GEN 'two of the farmers', behave similarly. 
As seen, these all-definites behave partly like plain definites and partly like indefinites. Like plain or bare definites they cannot stay within the predicate phrase, but like indefinites they are licensed in the I-domain.

Another interesting type of exceptions from the Indefiniteness Requirement is illustrated in (23) (see H. Sigurðsson 1989: 294-295; Jónsson 2000, 2005; Thráinsson 2007: 324 ff.; Indriðadóttir 2014). I refer to this construction as Low Subject Trapping, LST, as it has definite NPsubjects that are stuck or trapped within the predicate phrase, an issue I will return to shortly. ${ }^{23}$

(23) a. Рað er búin mjólkin.

there is finished milk-the

'There is no more milk (here)'

'The milk has run out'.

b. Раð er kaldur ofninn.

there is cold radiator-the

'The radiator is cold.'

c. Рað er brotinn diskurinn.

there is broken plate-the

'The plate is broken.'

d. Рað var bilaður skjárinn. ${ }^{24}$

there was broken monitor-the

'The monitor was out of order.'

e. Баð var bráðnaður snjórinn.

there was melted snow-the

'The snow had melted.'

LST is largely confined to the spoken language, and it is marked for many speakers. In an informant survey (with 710 and 709 informants,

$\overline{23}$ A related but a slightly different type pointed out by Rögnvaldsson (1982 [1990], 1984) is cases like "there shines always blessed sun-the", "there got-stuck bus-the on its way to the north", and "there is come guy-the who you met yesterday". See also H. Sigurðsson (1989: 294-295), and Thráinsson (2007: 325).

24 I find this less natural for plural subjects: ?Pað eru kaldir ofnarnir "there are cold the radiators", ?Раð voru bilaðir skjáirnir "there were broken monitors-the". 
respectively), the sentences in (23a) and (23d) were accepted by only $18 \%$ and $34 \%$, respectively (and rejected by $64 \%$ and $45 \%$, respectively) (Práinsson et al. 2015: 84). LST sentences express some previously unknown event (often unexpected but likely to happen in a given situation), and the subject must be non-topical (i.e., it must not have been spelled out in previous discourse). Thus, in the context "We checked both the stove and the radiator" one could not proceed by saying Pað var kaldur ofninn "there was cold oven-the" (one would have to say Ofninn var kaldur in that case). In the present tense, as in (23a), (23b), and (23c), LST sentences often initiate discourse. I could for example go into the kitchen and open the refrigerator to discover that there is no more milk there and then state (23a) to my partner. Alternatively, if my partner were to ask me 'What is the matter?' I could naturally answer with (23a) (or, in different situations, with (23b) or (23c)). It is thus difficult to create a natural context for present tense LST in a written informant survey. However, this does not extend to the past tense. The past tense sentences in (23d) and (23e) must be part of a larger discourse, where the background of the previously unknown event has been laid. For the sentence in (23d), the context was Ég komst ekki i tölvuna 'I could not get into the computer' (Dráinsson et al. 2015: 78). I will not speculate further on why so many informants in Práinsson et al. rejected LST sentences. The above-cited Icelandic linguists, who have discussed LST, all agree that many LST sentences are fully natural. The following discussion is based on my own intuitions. As far as I can judge, these intuitions are shared by many other speakers.

LST is constrained in various ways. First, it is commonly incompatible with individual level predicates (i.e., predicates that describe permanent properties of the subject): ??Pað er stór skjárinn "there is big monitorthe", and so on (Jónsson 2005: 457). Second, the subject cannot easily be animate, even with stage level predicates (describing non-permanent properties). See (24). ${ }^{25}$
a. * Рað er veikur kennarinn. there is sick teacher-the

\footnotetext{
$\overline{25}$ However, as pointed out by a reviewer, examples of this sort are variably marked. Thus, I find ?Sjáðu, pað er grár kötturinn "Look, there is gray cat-the" much better than *Sjáðu, pað er grár maðurinn "Look, there is gray man-the", even though it seems natural to interpret grár 'gray' here as an individual level predicate rather than as a stage level predicate.
} 
b. * Раð er fótbrotinn hesturinn. there is leg-broken horse-the

c. * раð er reiður strákurinn. there is angry boy-the

Third, the construction commonly requires clause-initial pað in declaratives, as opposed to questions. See (25). In certain contexts, however, this requirement is lifted, see $(25 \mathrm{c})$.
a. ?? Nú er búin mjólkin.
(OK: Nú er mjólkin búin)
now is finished milk-the
b. ?? Pá var bilaður skjárinn. (OK: Pá var skjárinn bilaður) then was broken monitor-the
c. Ég ætlaði að nota tölvuna en pá var bilaður
I intended to use computer-the but then was broken skjárinn.
monitor-the

'I intended to use the computer, but then the monitor was out of order.'

d. Er búin mjólkin?

'Is there no more milk here?'

e. Var bilaður skjárinn?

was broken monitor-the

'Was the monitor out of order?'

Fourth, LST is mainly found in the simple tenses, present and past. As we will see, it is sometimes grammatical in complex tenses (present and past perfects, etc.), but often it is less natural than in the simple tenses. See (26).

(26) a. ? Раð hefur sennilega verið búin mjólkin. there has probably been finished milk-the

b. ?? Раð hafði sennilega verið bilaður skjárinn. there had probably been broken monitor-the 
Fifth, the subject must be a definite full NP or DP (including DPs headed by a determiner, such as pessi ofn 'this radiator'). It cannot be an indefinite $\mathrm{NP}$, nor can it be a pronoun. See (27).
a. * Раð er búin mjólk/hún.
there is finished milk/she (= 'it')
b. * ${ }^{*}$ рað er kaldur ofn/hann. ${ }^{26}$
there is cold (a) radiator/he (= 'it')

Sixth, and most symptomatically, the subject is trapped within the predicate phrase; it cannot raise or float into the middle field. See (28) and (29).
a. * Pað er mjólkin búin. there is milk-the finished
b. * раð er bíllinn bilaður. there is car-the broken
a. ? Раð hefur sennilega verið búin mjólkin. $=(26 a)$ there has probably been finished milk-the

b. * Раð hefur sennilega verið mjólkin búin.

c. * Рað hefur sennilega mjólkin verið búin.

d. * Рað hefur mjólkin sennilega verið búin.

The examples in (23)-(29) all have an adjectival predicate. LST is also found for unaccusative and ergative verbs. See (30). ${ }^{27}$

$\overline{26}$ The indefinite NP is grammatical in a presentational sentence with a stage setting adverbial (cf. Milsark 1977): Pað er kaldur ofn í húsinu "there is (a) cold radiator in housethe".

27 In some cases of this sort (as in, e.g., "there broke plate-the") there is an innocence indication: "I am not responsible, it just happened/happens", but the same applies to "the plate broke". 
(30) a. Баð klárast mjólkin (ef pú drekkur hana alla). there gets-finished milk-the (if you drink it all) 'The milk will run out (if you drink it all).'

b. Раð slokknar ljósið (ef pú gerir petta). there goes-out light-the (if you do this) 'The light will go out (if you do this).'

c. Баð kólnaði ofninn. there cooled radiator-the 'The radiator got cold(er).'

d. Раð bilaði skjárinn. there broke monitor-the

'The monitor went out of order.'

e. раð bráđnaði ísinn. there melted ice-the 'The ice/ice-cream melted.'

f. Раð brotnaði diskurinn. there broke plate-the 'The plate broke.'

g. Ьаð rifnaði pokinn. there tore bag-the 'The bag burst.'

g. Раð lagaðist veðrið. there got-better weather-the 'The weather got better.'

Inasmuch as verbal LST is compatible with the complex tenses, it can be shown that the subject is trapped, cannot raise into the I-domain. See (31).

(31) a. ? Раð hefur sennilega bilað skjárinn. there has probably broken monitor-the

b. * Рað hefur sennilega skjárinn bilað.

c. * bað hefur skjárinn sennilega bilað. 
Unintentional causers in Icelandic are commonly expressed in hjá- 'by/ at' phrases (Wood 2013; the preposition hjá takes a dative complement). Hjá-phrases can also denote a possessor (E. Sigurðsson 2006; Práinsson, E. Sigurðsson \& Rögnvaldsson 2015) or a location. If such a phrase is added to (31a), the clause gains in acceptability (and so do clauses with other complex tenses). ${ }^{28}$ As shown in (32), the subject can either follow or precede the hjá-phrase.

a. Раð hefur sennilega bilað hjá henni skjárinn. there has probably broken by her.DAT monitor-the 'The monitor has probably broken down on her.' 'Her monitor has probably broken down.'

'She has probably unintentionally caused the/her monitor to break down.'

b. Раð hefur sennilega bilað skjárinn hjá henni,

The order in (32b) is slightly more marked than the one in (32a), but both are grammatical. This pattern is found for simple tense verbal and adjectival LST as well, as illustrated in (33) and (34).

a. Раð kólnaði hjá mér ofninn. there cooled by me.DAT radiator-the

'The radiator at my place got cold(er).'

'The radiator got cold(er) on me.'

'My radiator got cold(er).'

b. Pað kólnaði ofninn hjá mér.

$\overline{28}$ For example, clauses with future mun 'will' and the complex future koma til með að 'will', lit. "come to with to". See (i) for the latter:

(i) a. Раð kemur til með að kólna hjá pér ofninn. there comes to with to cool by you.DAT radiator-the

'The radiator at your place will get cold(er).'

'The radiator will get cold(er) on you.'

'Your radiator will get cold(er).'

b. Раð kemur til með að kólna ofninn hjá pér. 
(34) a. Баð er kaldur hjá mér ofninn.

there is cold by me.DAT radiator-the

'The radiator at my place is cold.'

'The radiator is (being) cold on me.'

'My radiator is cold.'

b. ' Pað er kaldur ofninn hjá mér.'

The $b$-examples in (32)-(34) might involve raising of the subject within the predicate phrase. Alternatively, the $a$-examples might involve raising of the hjá-phrase, or there might be two distinct base structures. I will not try to sort this out here (but see Wood 2013 for a discussion of the syntax of clauses with hjá-phrases). In any case, neither the subject nor the hjáphrase can move into the I-domain. See (35) and (36).

(35) a. аð hefur sennilega bilað skjárinn hjá henni. $=(32 b)$

b. * Баð hefur sennilega skjárinn bilað hjá henni.

c. * Pað hefur skjárinn sennilega bilað hjá henni.

(36) a. аð hefur sennilega bilað hjá henni skjárinn. = (32a)

b. * Рað hefur sennilega hjá henni bilað skjárinn.

c. * Pað hefur hjá henni sennilega bilað skjárinn.

The hjá-phrases have a special status. Other PPs cannot normally precede the subject in LST, see (37) and (38).

(37) a. Pað kólnaði ofninn í stofunni. there cooled radiator-the in living.room-the

'The radiator in the living room got cold(er).'

b. * Рað kólnaði í stofunni ofninn.

(38) a. Рað kólnaði ofninn í morgun. there cooled radiator-the in morning 'The radiator got cold(er) this morning.'

b. * Рað kólnaði í morgun ofninn. 
All the LST examples we have looked at so far have nominative subjects, but there are also cases of verbal LST with quirky subjects. ${ }^{29}$ See (39).

(39) a. Баð seinkar fluginu.

there delays flight-the.DAT

'The flight will be late.'

b. Раð verður flýtt klukkunni á morgun.

there will.be speeded clock-the.DAT on morrow

'The clock will be moved forward tomorrow.'

c. Баð fækkar alltaf ferðunum.

there get.fewer always trips-the.DAT

'The trips are getting fewer all the time.'

Finally, both nominative and quirky subjects are possible in some LST "non-raising raising infinitives", as in (40). ${ }^{30}$

(40) a. Баð virðist vera kaldur ofninn.

there seems be cold radiator-the.NOM

'The radiator seems to be cold.'

b. Баð virðist hafa seinkað fluginu.

there seems have delayed flight-the.DAT

'The flight seems to be/have been late.'

This (almost) completes my description of LST. It is the most detailed description of the phenomenon to date. The obligatory trapping of the definite subject within the predicate phrase is particularly intriguing. It might be related to two other phenomena, the (non-standard) New Passive and the Ergative-Impersonal Alternation. ${ }^{31}$ In both these phenomena,

29 There are no cases of adjectival LST with quirky subjects.

30 This is excluded in PRO infinitives but only marginally degraded in passive pað-initial ECM constructions: ? Рað var talinn vera kaldur ofninn i stofunni "there was believed be cold radiator-the.NOM in living.room-the".

31 Yet another phenomenon that might be related to LST is the so-called Impersonal Modal Construction, as in Nú/Dað verður að banna pessa hegðun.ACC "now/there must to forbid this behavior" 'This behavior must be forbidden (now)' (see H. Sigurðsson 1989; Wood 2017). 
definite NPs that are potential subject candidates must stay within the predicate phrase. Consider the New Passive first (see E. Sigurðsson 2017: $208 \mathrm{ff}$. and the references there, including Maling \& Sigurjónsdóttir 2002). It is illustrated in (41b) and (41c), in comparison with the standard or traditional passive in (41a); as shown in (41d) and (41e), the accusative NP cannot raise into the I-domain. DFT $=$ a default, non-agreeing $\mathrm{N} . \mathrm{SG}$ form. ${ }^{32}$

(41) a. Kennarinn var rekinn.

teacher-the.NOM was fired.NOM.M.SG

'The teacher was fired.'

b. Раð var rekið kennarann.

there was fired.DFT teacher-the.ACC

'The teacher was fired.'

'Somebody/They fired the teacher.'

c. Var rekið kennarann?

d. * Рað var kennarann rekið.

e. * Var kennarann rekið?

The Ergative-Impersonal Alternation is illustrated in (42) (for further discussion, see H. Sigurðsson 1989: 236-237, 289-292). The ergative version in (42a) has regular NP-movement to subject, whereas the impersonal version in (42b) and (42c) has the NP embedded in a preposition phrase; as shown in (42d) and (42e), the preposition NP complement cannot raise into the I-domain.
a. Kertið
slokknaði.
candle-the.NOM went.out
'The candle went out.'
b. Баð slokknaði á kertinu.
there went.out on candle-the.DAT
'The candle went out.'
c. Slokknaði á kertinu?
d. * pað slokknaði kertinu á.
e. * Slokknaði kertinu á?

$\overline{32}$ Parallel patterns are found for datives: Баð var boðið kennaranum "there was invited teacher-the.DAT" vs. *Dað var kennaranum boðið "there was teacher-the.DAT invited", and so on. 
In both the New Passive and the impersonal PP clauses, though, the low NP is assigned case within the predicate phrase, so its inability to raise into the I-domain might be taken to be an instantiation of (criterial) freezing in the sense of Chomsky (2001: 6) or Rizzi (e.g., 2007), saying roughly that an NP that has checked all its features (case, etc.) gets frozen in place and cannot move any further (a reasonable conjecture). The trapping of the subject in LST relates to information structure; as we have seen the trapped subject must not be topical. Its position might be a criterial focus position, for a non-topical but a situation-given subject, but it is difficult to find any evidence bearing on the issue, apart from the trapping itself. Alternatively, or in addition, the subject cannot raise out of the predicate phrase as it does not match a Topic feature or Topic features high in the clausal structure. In any event, the subject is commonly nominative in LST, so, on widely adopted approaches to NP-movement (e.g., Chomsky 1981), it "should" move into the I-domain to get its case checked in a (more) local relation to Infl. We must conclude that LST is unrelated to specific cases - something different from case is responsible for the trapping. In addition, as we saw in section 2, Subject Float is unrelated to case. In Subject Float, the indefinite subject may raise out of the predicate phrase into the I-domain, but the float applies to subject NPs regardless of their case marking.

A very sharp difference between the New Passive and the impersonal PP clauses on one hand and LST on the other hand is that the predicate phrase internal argument can easily be a pronoun in the former but not in the latter. See the contrasts between (43) and (44).
a. Рað var rekið hana.
New Passive
there was fired her
'She was fired.'
'Somebody/They fired her.'

b. Баð slokknaði á pví.

there went-out on it

'It went out.'
a. * Рað er kaldur hann.
Adjectival LST
there is cold he (= 'it')
b. * Рað kólnaði hann.
there cooled he (='it')
Verbal LST

Impersonal PP clause 
This sharp difference has gone unnoticed hitherto, for example in my own works. In H. Sigurðsson (2010), I treated definite NPs on a par with pronouns. Although treating pronouns and definite full NPs alike might be sufficient for English it is evidently not accurate for Icelandic. A possible line of reasoning here is that pronouns in non-transitive constructions differ from full NPs in that they must normally be in the vicinity of Person checking features in the C-/I-domain, an effect that has commonly, and misleadingly, been attributed to case or to the Extended Projection Principle. There are, however, exceptions from this, where the NP is "shielded" from high Person checking by an intervening element, including passive morphology in the New Passive and prepositions (in Icelandic, as opposed to for example English, which has pseudo passives, absent from Icelandic). These intervening elements seem to be heading strong phases, thus having their own Person checking features, thereby blocking matching of Person checking features in the C-/I-domain by regular minimality (see the discussion in H. Sigurðsson 2010, 2011, 2012; Legate 2014; E. Sigurðsson 2017).

NP raising to Spec,IP arguably involves matching of Person checking features in the C-/I-domain. In addition, the Subject Float and LST facts discussed here suggest that it also involves matching of a Topic feature or Topic features high in clausal structure.

\section{Concluding remarks}

In this article I have described and discussed two sets of perplexing and poorly understood (in)definiteness facts in Icelandic, Low Subject Trapping, applying to some definite subjects, and Subject Float, applying to indefinite subjects in presentational (and related) constructions. The facts described here show that some definite subjects must be spelled out in the complement position within the predicate phrase and that quantified indefinite subjects can be spelled out in a number of positions in the middle field, above the predicate (in addition to the complement position). The licensing of subject NPs in the various positions is unrelated to specific cases, thus speaking loud and clearly against the assumption (Vergnaud's conjecture) in Chomsky (1981) and much subsequent writings that case plays an essential role in NP licensing. Case marking and case agreement in Icelandic infinitives also demonstrate very clearly that the assumption is unfounded (see H. Sigurðsson 2008, 2012, and the references there). It is difficult to test this assumption in languages such as English, with 
barely any case marking, but it can be tested in Icelandic, and the results are unequivocal: Case does not account for argument licensing.

In all fairness, it must be added that Chomsky has abandoned his original "case story", albeit only reluctantly in passing ("Case assignment is divorced from movement", 2001: 17). However, the field has not followed in his footsteps (see, e.g., Lasnik 2008; Legate 2008). A much weaker approach, in the spirit of Sapir (1921), might be upheld, namely, that cased NPs are partly licensed by having some case, regardless of which, but that is a vague statement with limited predictive power. Nominative case, abstract or not, is unrelated to subject licensing in Spec,IP, which instead seems to boil down to Person and Topic matching.

To partially rescue Vergnaud's conjecture, one might perhaps want to invoke a parametric approach, and pursue the idea that NPs in caseless and case poor languages are licensed by abstract Case, in contrast to NPs in case richer languages. However, such a theory would escape all potential tests, and thus be non-scientific guesswork.

If linguistics were like the natural sciences, Vergnaud's conjecture would have been generally discarded a long time ago, and the whole field would be looking for alternative accounts of NP licensing. Unfortunately, that is not the case, but hopefully it will be.

\section{References}

Alexiadou, Artemis \& Elena Anagnostopoulou. 2001. The subject-in-situ generalization and the role of case in driving computations. Linguistic Inquiry 32. 193-231. doi:10.1162/00243890152001753.

Andrews, Avery. 1976. The VP complement analysis in Modern Icelandic. NELS [Proceedings of the Annual Meeting of the North East Linguistics Society] 6. 1-21. [Reprinted in Joan Maling \& Annie Zaenen (eds), 1990, Modern Icelandic syntax, 165-185. San Diego: Academic Press.]

Belletti, Adriana. 1988. The case of unaccusatives. Linguistic Inquiry 19. 1-34.

Bobaljik, Jonathan. 1999. Adverbs: The hierarchy paradox. Glot International 4(9/10). 27-28.

Bošković, Željko. 2004. Be careful where you float your quantifiers. Natural Language and Linguistic Theory 22. 681-742. doi:10.1007/s11049-004-2541-z. Chomsky, Noam. 1981. Lectures on government and binding. Dordrecht: Foris. 
Chomsky, Noam. 2001. Derivation by phase. In Michael Kenstowicz (ed.), Ken Hale: A life in language, 1-52. Cambridge, MA: The MIT Press.

Elisabet, Engdahl. 2017. Expletive passives in Scandinavian - with and without objects. In Laura R. Bailey \& Michelle Sheehan (eds.) Order and structure in syntax II: Subjecthood and Argument structure [In the Open Generative Syntax series] 289-306. Berlin: Language Science Press. doi:10.5281/zenodo.1115573. Engdahl, Elisabet, Joan Maling, Halldór Ármann Sigurðsson \& Annie Zaenen. 2018. Presentational sentences in Icelandic and Swedish: Roles and positions. Working Papers in Scandinavian Syntax 101. 1-28.

Holmberg, Anders. 2002. Expletives and agreement in Scandinavian passives. Journal of Comparative Germanic Linguistics 4. 85-128. doi:10.1023/A:1015882307080.

Indriðadóttir, Ingunn Hreinberg. 2014. Er búin mjólkin? [“Is ran out milk-the?”]. Reykjavík: University of Iceland MA thesis.

Jónsson, Jóhannes Gísli. 1996. Clausal architecture and case in Icelandic. Amherst: University of Massachusetts $\mathrm{PhD}$ dissertation.

Jónsson, Jóhannes Gísli. 2000. Definites in Ielandic existentials. In Guðrún Pórhallsdóttir (ed.), The Nordic languages and modern linguisics X, 125-134. Reykjavík: Institute of Linguistics, University of Iceland.

Jónsson, Jóhannes Gísli. 2005. Merkingarhlutverk, rökliðir og fallmörkun [Thematic roles, arguments, and case]. In Höskuldur Práinsson [Thráinsson] (ed.), Setningar: Handbók um setningafrceði [Sentences: A Syntax Handbook], 435-458. Reykjavík: Almenna bókafélagið.

Lasnik, Howard. 1992. Case and expletives. Linguistic Inquiry 23. 381-405.

Lasnik, Howard. 2008. On the development of case theory: Triumphs and challenges. In Robert Freidin, Carlos P. Otero \& Maria Luisa Zubizarreta (eds), Foundational issues in linguistic theory: Essays in honor of Jean-Roger Vergnaud, 17-41. Cambridge, MA: MIT Press. doi:10.7551/mitpress/9780262062787.003.0003.

Legate, Julie Anne. 2008. Morphological and abstract Case. Linguistic Inquiry 39. 55-101. doi:10.1162/ling.2008.39.1.55.

Legate, Julie Anne. 2014. Voice and v: Lessons from Acehnese. Cambridge, MA.: MIT Press. doi:10.7551/mitpress/9780262028241.001.0001.

Maling, Joan \& Sigríður Sigurjónsdóttir. 2002. The new impersonal construction in Icelandic. The Journal of Comparative Germanic Linguistics 5. 97-142. doi:10.1023/A:1021224923742.

Milsark, Gary L. 1977. Toward an explanation of certain peculiarities of the existential construction in English. Linguistic Analysis 1. 1-29.

Platzack, Christer. 1983. Existential sentences in English, German, Icelandic, and Swedish. In Fred Karlsson (ed.), Papers from the seventh Scandinavian conference of linguistics, 80-100. Helsinki: Department of General Linguistics, University of Helsinki. 
Rizzi, Luigi. 2007. On some properties of criterial freezing. Studies in Linguistics. CISCL Working Papers on Language and Cognition. 2007(1). 145-158.

Rögnvaldsson, Eiríkur. 1982 [1990]. Um orðaröð og faerslur í islensku. [On word order and movements in Icelandic.] Reykjavík: University of Iceland MA thesis [published 1990: Reykjavík: Institute of Linguistics, University of Iceland].

Rögnvaldsson, Eiríkur. 1984. Rightward displacement of NPs in Icelandic: Formal and functional characteristics. In Kristian Ringgaard \& Viggo Sørensen (eds.), The Nordic languages and modern linguistics 5. 361-368.

Safir, Ken. 1985. Syntactic chains. Cambridge: Cambridge University Press.

Sapir, Edward. 1921. Language. New York: Hartcourt, Brace, and Javanowitch.

Sigurðardóttir, Sigríður \& Thorhallur Eythórsson. 2017. Weather pro(s) and cons. Poster presented at DiGS [Diachronic Generative Syntax] 19, Stellenbosch, South Africa.

Sigurðsson, Einar Freyr. 2006. Tölvan hjá mér er biluð: Notkun forsetningarinnar hjá $i$ eignarmerkingu [The computer at me is out of order: The use of the preposition hjá 'by, at' in a possessive sense]. Reykjavík: University of Iceland BA thesis.

Sigurðsson, Einar Freyr. 2017. Deriving case, agreement and voice phenomena in syntax. Philadelphia: University of Pennsylvania PhD dissertation.

Sigurðsson, Halldór Ármann. 1989. Verbal syntax and case in Icelandic. Lund: University of Lund PhD dissertation. [Republished 1992 in Reykjavík: Institute of Linguistics, University of Iceland].

Sigurðsson, Halldór Ármann. 1990. V1 declaratives and verb raising in Icelandic. In Joan Maling \& Annie Zaenen (eds), Modern Icelandic Syntax, 41-69. San Diego: Academic Press.

Sigurðsson, Halldór Ármann. 1996. Icelandic finite verb agreement. Working Papers in Scandinavian Syntax 57. 1-46.

Sigurðsson, Halldór Ármann. 2000. The locus of case and agreement. Working Papers in Scandinavian Syntax 65. 65-108.

Sigurðsson, Halldór Ármann. 2008. The case of PRO. Natural Language \& Linguistic Theory 26. 403-450. doi:10.1007/s11049-008-9040-6.

Sigurðsson, Halldór Ármann. 2010. On EPP effects. Studia Linguistica 64. 159189. doi:10.1111/j.1467-9582.2010.01171.x.

Sigurðsson, Halldór Ármann. 2011. On the new passive. Syntax 14. 148-178. doi:10.1111/j.1467-9612.2010.00150.x.

Sigurðsson, Halldór Ármann. 2012. Minimalist C/case. Linguistic Inquiry 43. 191227. doi:10.1162/LING_a_00083.

Sigurðsson, Halldór Ármann. 2018. Icelandic declarative V1: A brief overview. Working Papers in Scandinavian Syntax 101. 49-55.

Sportiche, Dominique. 1988. A theory of floating quantifiers and its corollaries for constituent structure. Linguistic Inquiry 19. 425-449.

Thráinsson, Höskuldur. 1979. On complementation in Icelandic. New York: Garland. 
Thráinsson, Höskuldur. 2007. The syntax of Icelandic. Cambridge: Cambridge University Press. doi:10.1017/CBO9780511619441.

práinsson [Thráinsson], Höskuldur, Einar Freyr Sigurðsson \& Eiríkur Rögnvaldsson. 2015. Eignarsambönd [Possessive constructions]. In Höskuldur Práinsson, Ásgrímur Angantýsson \& Einar Freyr Sigurðsson (eds.), Tilbrigði i islenskri setningagerð II [Variation in Icelandic syntax II], 233-274. Reykjavík: Institute of Linguistics, University of Iceland.

práinsson [Thráinsson], Hökuldur, Sigríður Sigurjónsdóttir, Hlíf Árnadóttir \& Pórhallur Eypórsson, 2015. Um polmynd, germynd og pað [About passive and active voice and $p a ð$ ['it, there']]. In Höskuldur Práinsson, Ásgrímur Angantýsson \& Einar Freyr Sigurðsson (eds.), Tilbrigði i íslenskri setningagerð II [Variation in Icelandic syntax II], 77-120. Reykjavík: Institute of Linguistics, University of Iceland.

Vangsnes, Øystein Alexander. 2002. Icelandic expletive constructions and the distribution of subject types. In Peter Svenonius (ed.), Subjects, expletives, and the EPP, 43-70. Oxford: Oxford University Press.

Vikner, Sten. 1995. Verb movement and expletive subjects in the Germanic languages. Oxford: Oxford University Press.

Wood, Jim. 2013. The unintentional causer in Icelandic. NELS [Proceedings of the Annual Meeting of the North East Linguistic Society] 41. 273-286.

Wood, Jim. 2017. The accusative-subject generalization. Syntax 20. 249-291. doi:10.1111/synt.12138. 